\title{
Cinema e Acontecimento Comunicacional: a experiência cinematográfica pode ser transcendente?
}

\section{Wilson Roberto Vieira Ferreira}

Professor em Estudos da Semiótica e Linguagem Audiovisual pela Universidade Anhembi Morumbi/SP. Jornalista e editor do blog "Cinema Secreto: Cinegnose". Pesquisador e autor dos livros O Caos Semiótico e Cinegnose pela Editora Livrus e coautor do Dicionário da Comunicação organizado por Ciro Marcondes Filho pela editora Paulus.

\section{Resumo}

Desde as suas origens o cinema traria ainda dentro de si a potencialidade em transcender a si mesmo e mudar vidas de espectadores ao transformar a experiência estética em um acontecimento. O cinema é um sintoma da sociedade mas, por outro lado, é um elemento operacional do contínuo midiático. Porém, em certos momentos e em dados contextos podem ocorrer experiências de quebras e brechas no princípio de realidade. A partir dos conceitos de Acontecimento e Comunicação seria possível capturar e refletir esses momentos efêmeros de ruptura.

Palavras-chave: Cinema, Comunicação, Acontecimento Comunicacional

\section{Abstract}

From its origins the cinema would bring within it the potential to transcend yourself and change lives of spectators by turning the aesthetic experience into a happening. The film is a symptom of society but on the other hand, is an operating element of the continuous media. However, at certain times and in certain contexts may occur experiences breaks and loopholes in the reality principle. From the Happening and Communication concepts it would be possible to capture and reflect these ephemeral moments of rupture.

Keywords: Cinema, Communication, Communicational Happening

\section{Resumen}

Desde sus orígenes el cine traería en sí el potencial de trascender a sí mismo y cambiar la vida de espectadores girando la experiencia estética en uno acontecimiento. La película es un síntoma de la sociedad pero, por otro lado, es un elemento de mando de los medios de comunicación continua. Sin embargo, en ciertos momentos y en ciertos contextos puede producir experiencias del ruptura y las lagunas en el principio de realidad. Desde el conceptos de Acontecimiento y Comunicación sería posible capturar y reflejar estos momentos efímeros de ruptura.

Palabras clave: Cine, Comunicación, Acontecimiento Comunicacional 


\section{Introdução}

Para a maioria dos espectadores, ir ao cinema não é uma atividade que esteja associada ao perigo e comportamentos transgressivos. Tido como um local onde fantasias podem ser vividas e tudo pode acontecer em um universo ficcional, está mais comumente associado ao entretenimento ou, no mínimo, a uma fuga dos problemas ou do esquecimento momentâneo dos aborrecimentos do dia-a-dia.

Mas nem sempre foi assim ou, talvez, nunca tenha sido. De um lado há uma história descrita por pesquisadores que localiza no chamado primeiro cinema um tipo de experiência estética que não se resumia unicamente a uma forma de entretenimento: pelo contrário, era uma forma de experiência que poderia transformar vidas; de outro, pesquisas críticas que descrevem o cinema e a própria experiência estética como uma arena de tumulto e contenção, quebras e retornos à ordem, crítica e reação.

Para esses pesquisadores, desde o primeiro cinema e a posterior industrialização, enquadramento e controle, o cinema traria ainda dentro de si a potencialidade em transcender a si mesmo, mudar vidas de espectadores, transformar a experiência estética em um acontecimento.

\section{Audiência como parte do show}

Em uma perspectiva político-ideológica Steven Ross descreve como a produção cinematográfica exibida desde os primeiros nickelodeons em 1905 até o princípio da década de 1920 representou os crescentes conflitos entre capital e trabalho, greves, a precarização do trabalho e o sindicalismo (ROSS, 1999). Antes de Hollywood descobrir as narrativas baseadas em fantasias que transcendiam as classes sociais ("cross-class fantasies”), diversos pequenos estúdios concentravam seus filmes em melodramas inspirados no cotidiano de trabalhadores e imigrantes.

Ross descreve o maravilhamento de um público formado pelos estratos inferiores da sociedade (o primeiro público do cinema) ao ver suas vidas, problemas urbanos e trabalhistas representado em narrativas visuais nas telas. Cineastas e produtoras como American Mutuoscope e American Biograph realizavam em 1910 inúmeros filmes com diversos aspectos da vida das classes trabalhadoras que formavam um arco que se estendia dos inócuos romances, melodramas e comédias, passando por temas focados em problemas sociais, trabalhistas e sindicais nas relações capital-trabalho até chegar aos filmes explicitamente ideológicos e de confronto focando os violentos choques (greves e repressão policial) entre empregadores e empregados.

As exaustivas descrições e documentações de Ross sobre esse período inicial do cinema norte-americano demonstram como as primeiras salas de projeções tornavam-se verdadeiros acontecimentos: de um lado, o cinema era encarado pelo seu público como um remédio rápido para a dor e tédio do trabalho diário por meio do esquecimento ou como oportunidade única que permitia deixar a fantasia assumir o comando por alguns momentos nas suas vidas; e do outro os filmes era facilmente integrados à vida dos trabalhadores por fazê-los se reconhecerem nas imagens. De Griffith a Chaplin, todos eles retrataram injustiças sociais e mazelas das vidas urbanas que, no final, foram experiências que vivenciaram em suas próprias vidas esses diretores e reconhecidas pelas audiências populares. 
A ascensão de Hollywood como indústria a partir de 1920, o impacto da Revolução Bolchevique na Rússia de 1917 e o movimento anticomunista nos EUA (onde novos filmes passaram, por exemplo, a identificar sindicalistas como comunistas estupradores de jovens indefesas), a padronização das salas de exibição como luxuosos palácios para as classes médias e o domínio das narrativas organizadas em torno de "cross-class fantasies" (narrativas apresentando garotos pobres que se apaixonam por garotas ricas ou homens ricos que se casam com garotas pobres, enfatizando o amor e a harmonia entre as classes sociais) domesticaram a imagem e a fúria desses primeiros tempos, reduzindo o acontecimento das sessões de cinema em entretenimento padronizado e controlado pelo Código Hays de restrição temática e moral.

O detalhista levantamento de Ross sobre os primeiros anos do cinema norte-americano nos oferece uma primeira aproximação entre cinema e acontecimento. A atmosfera reinante nas antigas salas de projeção, o filme como um evento que disparava o fenômeno da interação, reconhecimento de si mesmo e participação. Para o pesquisador, esses filmes radicais foram muito pouco bem sucedidos como instrumentos de propaganda ou de conscientização político-ideológica. Seu principal valor esteve menos na esfera racional do que nos aspectos da experiência estética (festa, participação, interatividade etc.), isto é, em um valor incorpóreo, singular que permeava o "aqui e agora" desses filmes e que os tornava eventos que produziam acontecimentos.

Declarações de observadores da época citados por Ross dizendo que "sinto que eles [os espectadores] estão recebendo algo de fora da vida” (ROSS, 1999, p. 20) ou "quando você assiste a um filme, você fica tão exausto que quando chega em casa dorme como uma brisa" (ROSS, 1999, p. 24), relatando a energia e eletricidade coletiva no evento fílmico comprovam que o cinema era muito mais do que entretenimento, mas um acontecimento que, de alguma forma, quebrava a sucessão temporal cotidiana.

\section{Escapar da realidade}

Desse primeiro cinema ficou apenas o desejo de quebrar a tediosa rotina diária de trabalho dentro de um lugar onde as fantasias assumiam o comando e tudo podia acontecer. Só que, agora, em silêncio, todos mudos, lado a lado em luxuosos palácios em que se converteram os cinemas.

Essa passividade e silêncio do espectador convivendo em aparente harmonia com o desejo de quebra da rotina por obra de algo que venha "de fora da vida" cria uma situação contraditória que poderíamos conceituar como de duplo vínculo.

Retirando as diversas camadas ou racionalizações sobre os motivos que levam pessoas a passarem duas horas em um cinema (renovação cultural, ter assunto para conversas, diversão etc.), o desejo pela quebra da rotina como motivação de última instância está demonstrado em diversas pesquisas. Por exemplo, em pesquisa realizada pela Reuters e Ipsos em 2010 com 24 mil adultos em 23 países revelou que 42\% tendem a ir ao cinema com maior frequência possível para "escapar da realidade", isto é, duas em cada cinco pessoas admitiram o desejo da "quebra da rotina" (IPSOS \& REUTERS, 2010).

Para além das interpretações mais superficiais ou moralistas da expressão "escapar da realidade" (como mero "escapismo", "alienação", "futilidade" ou "diversão"), estaria por trás dessa expressão o desejo do espectador em buscar um evento que produza um 


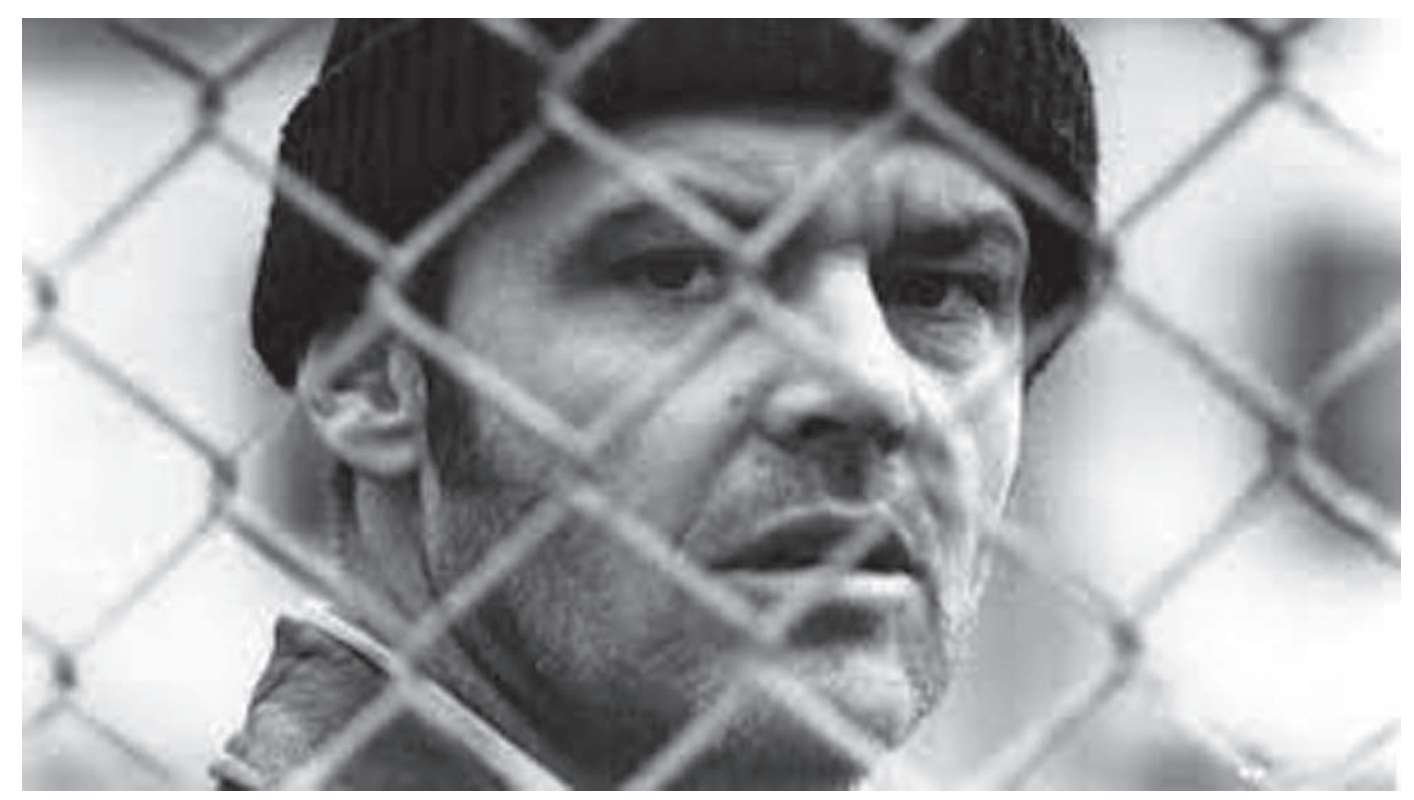

Jack Nicholson em $\bigcirc$ estranho no ninho (1975), de Milos Forman.

acontecimento, mesmo que transitório: a suspensão da ordem, aqui compreendida em um primeiro momento como quebra da suspensão temporal dos eventos do dia-a-dia.

Portanto, temos de um lado a passividade e o silêncio do espectador e, do outro, a busca no cinema de uma dimensão que esteja "fora da vida". No início a experiência da "quebra da rotina" sucedida pelo retorno forçado do espectador ao cotidiano do qual queria escapar.

\section{Impulso por transcendência}

Talvez Theodor Adorno tenha sido o primeiro a compreender o que estamos conceituando como duplo vínculo. Em primeiro lugar, ao associar o impulso por transcendência ao próprio objeto artístico. Quando Adorno apontava para a alteridade e transcendência contidas na arte, ele aproximava-se da temática central da "Dialética Negativa": a busca do "inteiramente outro", do "plenamente diferente", do "diferente por excelência”, ou seja, aquilo que está além da representação. Adorno pensava o conceito de transcendência não no sentido religioso como epifania ou experiência mística de fato, de uma forma positiva. Afinal, para Adorno as obras de arte são, antes de tudo, artefatos, algo fabricado pelo espírito humano e não uma experiência místico-religiosa.

Como obra do espírito, a arte tendencialmente quer ultrapassar a si mesma, ir além da sua estrutura, do seu medium, do seu ambiente perceptivo.

Por outro lado, isso acaba criando uma tensão da arte com a sociedade e do próprio espírito com o mundo. Para Adorno, essa tensão era a negação do Todo (social, político, econômico etc.) e o vislumbre de algo inteiramente outro por meio de uma experiência mínima, única, precária. A “metafísica em queda” proposta por Adorno na "Dialética Negativa" é essa busca das experiências fugazes, singulares que apontam para um "transmundo" (ADORNO, 1991). 
Por essa natureza contraditória (transcendência e imanência) uma espécie de duplo vínculo estaria presente tanto no objeto artístico quanto na sua própria recepção como, por exemplo, no rádio e na música popular:

"Toda a esfera de diversão comercial barata reflete esse duplo desejo. Ela induz o relaxamento porque é padronizada e pré-digerida. Sendo padronizada e pré-digerida serve, na psicologia familiar das massas, para poupar-lhes o esforço dessa participação (mesmo de ouvir e observar), sem o qual não pode haver receptividade à arte. Por outro lado, os estímulos que ela providencia permitem uma escapadela da monotonia do trabalho mecanizado." (ADORNO, 1986, p. 136).

Escapar à monotonia e poupar esforços são movimentos incompatíveis. Como afirma Adorno, a indústria cultural lida com um problema insolúvel: ao mesmo tempo oferecer produtos novos e estimulantes que façam o receptor escapar da rotina e, simultaneamente, tornar essa novidade padronizada e familiar para relaxar e poupar esforços. Nesta corda bamba equilibra-se a indústria cultural ao ter que criar um entretenimento que mantenha a ordem institucional e, ao mesmo tempo, ofereça a esperança de rompê-la.

Para Adorno, isso significa que a noção de entretenimento como mera distração, escapismo ou alienação deve ser questionada. Há uma dimensão muito mais complexa que deve ser entendida à luz das mudanças estruturais da esfera de lazer proporcionadas pela forma-mercadoria. Para além da interpretação dominante que enfoca o pensamento de Adorno como pessimista, ele nos fornece importantes subsídios dentro da sua "Dialética Negativa": a existência de elementos potencialmente transcendentes no interior das formas culturais comerciais.

Aluno de Adorno, Dieter Prokop vai aplicar em análises fílmicas do chamado "produto cultural de monopólio" essa abordagem adorniana. Prokop vai analisar a repetição da "fantasia-clichê" de "questionamento e reconstrução da ordem":

"Nos produtos de monopólio domina o esquema de questionamento e reconstrução da ordem. Os valores vigentes são desrespeitados, atacados e novamente restaurados. É um jogo necessário para a fantasia, pois se repete todas às vezes na estrutura do produto e nas expectativas." (PROKOP, 1986, p. 178).

Diante do movimento pendular entre "tédio" e "fascinação" (entre a necessidade industrial do padrão e a necessidade dos receptores pela novidade), Prokop fala de uma necessidade de "harmonia" por parte da psicologia dos espectadores, uma situação onde fascinação e tédio não são mais excludentes ou problemáticos, mas onde o tédio já está dentro da fascinação:

'O tédio que surge aqui não é somente o 'estar entediado', como ocorre quando se é obrigado a participar de algo que não deseja. É um tédio dentro da fascinação - e na moderação. (...) Por outro lado os telespectadores não querem se entediar. Anseia- se por uma harmonia difusa, que é, por assim dizer, arranjada carinhosamente para o receptor. Deseja- se encostar na poltrona e ser alimentado com imagens e sons. Neste clima fica-se disposto a se identificar com as coisas mais estúpidas só para satisfazer a essa necessidade. O sujeito fica fixado no ver, ouvir eler sem que lhe possam ser permitidos excessos voyeurísticos, desfrutes. A 'quebra' logo precisa ser nova- 
mente neutralizada. Ela não pode incomodar a rotina. Uma necessidade por harmonia pode ser satisfeita pelos meios de comunicação." (PROKOP, 1986, pp. 154-155).

O telespectador quer fugir da rotina do trabalho mecânico ao chegar em casa e ligar a televisão, busca algo estimulante, novo e enriquecedor. Mas, contraditoriamente, aquilo que é excessivamente novo pode trazer desordem, inquietação e exigir do receptor posicionamento, participação. Quebras de ritmo trazidas por elementos estéticos ou de conteúdos inovadores devem ser neutralizados pelo clichê. Prokop, portanto, ressalta a necessidade psicológica por harmonia através de imagens e sons, harmonia que induz ao relaxamento e novas energias para enfrentar a rotina do trabalho mecanizado do dia seguinte.

Portanto, tanto em Adorno quanto em Prokop encontramos mais elementos para a nossa aproximação entre Cinema e Acontecimento: a interdição do acontecimento por meio de um jogo de duplo vínculo onde o espectador jamais ganha.

\section{Duplo vínculo e esquizofrenia}

Podemos também encontrar mais elementos que nos ajudem a desenvolver esse conceito de duplo vínculo em Jason Horsley (HORSLEY, 2009). Ele descreve a história do "cinema esquizo": uma dualidade entre momentos em que Hollywood permitiu a produção de filmes "esquizofrenicamente perturbadores e subversivos" e filmes "recuperativos", verdadeiros neurolépticos onde paranoia e psicose das narrativas fílmicas são submetidas aos limites racionalizantes do mercado.

Horsley faz uma distinção entre o "cinema esquizo" (marcado por narrativas paranoicas e protagonistas psiquicamente instáveis e marcados pela revolta e cinismo) e o traço esquizoide presente no próprio dispositivo, linguagem e recepção cinematográfica.

Para Horsley o florescimento do cinema como indústria nos EUA somente foi possível pela própria natureza esquizo do dispositivo que veio de encontro a uma sociedade marcada pela paranoia, desde a transmissão radiofônica de Guerra dos Mundos em 1938 que levou ao pânico milhões de ouvintes na Costa Leste que acreditaram estar sob ataque de invasores marcianos. Esse traço esquizo do dispositivo estaria presente na passividade (no sentido cinemático da passividade corporal em relação à atividade mental) e a suspensão da descrença produzida pelas técnicas narrativas do roteiro e pelo "realismo cinematográfico" (narrativa clássica) de edição e montagem.

Além da característica da passividade, a paranoia em relação à ameaça do Outro é um dos traços constitutivos da condição esquizofrênica. Partindo das considerações de Freud em O Mal Estar da Civilização e tomando a esquizofrenia como um sintoma de uma relação patológica com o Outro (Sociedade, Cultura, Cotidiano etc.) Horsley vai estabelecer esse movimento pendular entre o cinema esquizo onde o Outro é identificado com alienígenas, monstros, femme fatales e a própria sociedade doentia e corrupta (temática cujo auge foi nos anos 1970 em filmes como Um Estranho no Ninho, Taxi Driver, Sem Destino, Perdidos na Noite etc.) e o "cinema recuperativo" onde o mal estar em relação ao Outro é reduzido a uma questão de assepsia e controle: extermínio e violência sadística e exibicionista.

Horsley faz um diagnóstico da sociedade norte-americana a partir da dualidade entre os filmes "esquizo" e "recuperativos" da seguinte maneira: de um lado, a condição esquizofrênica de viver em sociedade cuja estrutura nos impõe a passividade e 


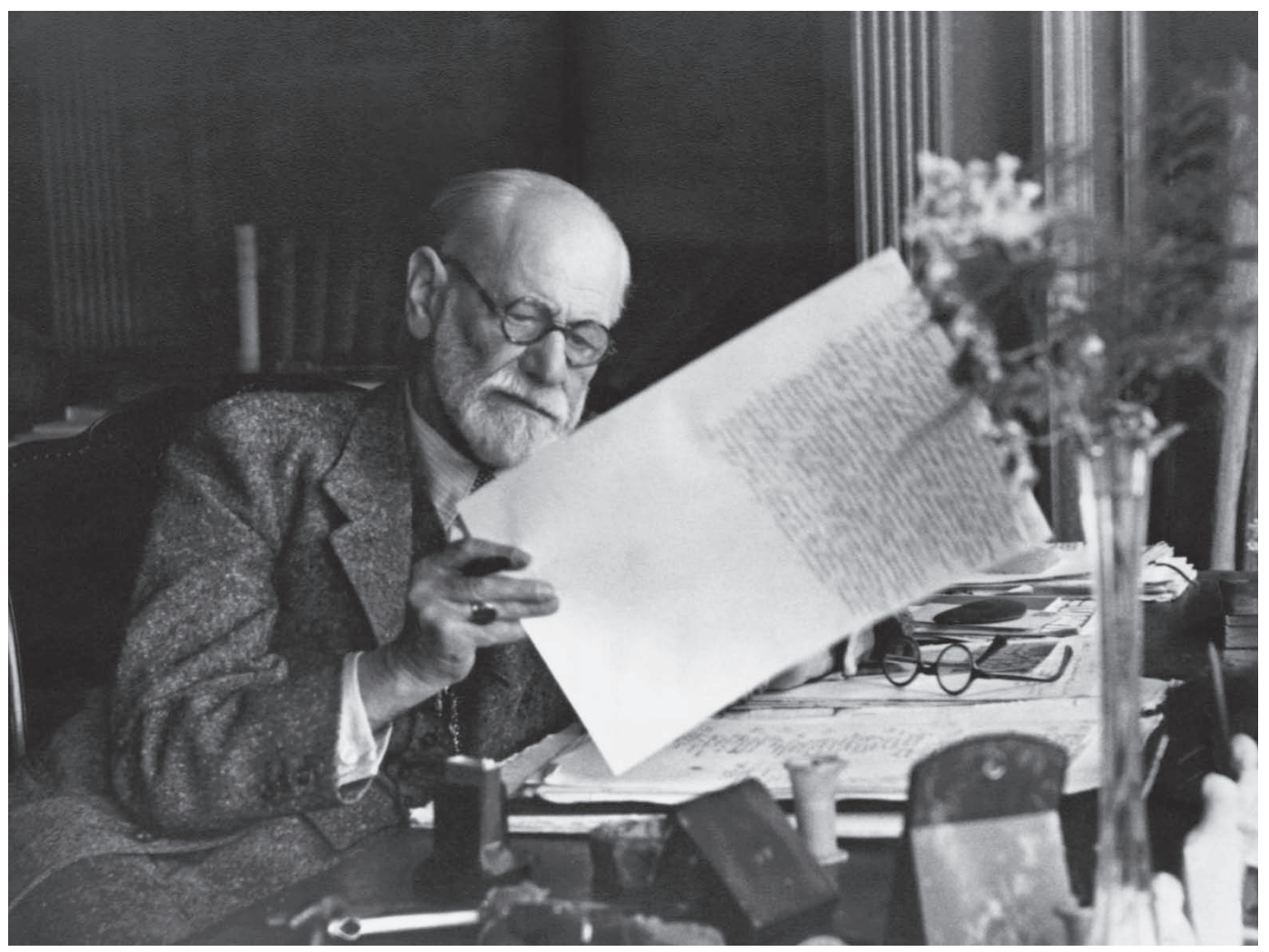

Sigmund Freud (1856-1839).

dissociação entre o ego e os múltiplos papéis do cotidiano; e do outro, uma relação particular que os filmes recuperativos criam um processo de aceleração dessa passividade e dissociação ao vermos a projeção fílmica da realidade e de nós mesmos nos tornando imunes às consequências.

O pesquisador descreve basicamente três momentos em que Hollywood permitiu a produção dos filmes esquizo: no filme noir das décadas de 1930-40 (onde surgiram os três modos de representação do mal estar contemporâneo na figura de três protagonistas arquetípicos - “o viajante", "o detetive" e "o estrangeiro" ), nos anti-heróis revoltados, desequilibrados e cínicos dos anos 1970 (de Sem Destino a Scarface) e no último revival nas décadas 1990-2000 representado pelo súbito interesse de produtores de Hollywood por escritores gnósticos como Philip K. Dick e Cornac McCarthy (respectivamente O Homem Duplo e A Estrada), roteiristas como Charlie Kauffman (Quero ser John Malkovitch e Brilho Eterno de Uma Mente Sem Lembranças) com profundos temas, simbologias e iconografias gnósticas e diretores como David Lynch (Inner Empire e Mulholland Drive) ou Scorsese (Ilha do Medo).

A visão de Horsley do cinema como forma de diagnóstico de um mal estar social nos oferece outra contribuição para o tema Cinema e Acontecimento ao suscitar a seguinte questão: por ser um cinema cujas narrativas exploram a paranoia, estados alterados de consciência e a denúncia da falsidade das estruturas sociais, a recepção dos filmes esquizo poderiam produzir acontecimento? Poderiam esses filmes, em contraste com o "cinema recuperativo", arrancar o espectador da passividade e criar não tanto reflexão ou conscientização (eventos racionais), mas choque, mal estar ou uma forma incorpórea de evento que transcenda o indivíduo do cotidiano ou, pelo menos, quebre a sequência temporal do dia-a-dia? 
Para iniciarmos uma reflexão dessa natureza precisamos em primeiro lugar esclarecer um pouco mais os conceitos de "evento" e "acontecimento".

\section{Acontecimento para os filósofos e para a comunicação}

Os eventos ou fatos seriam aqueles de natureza ruidosa, escandalosa: casos naturais, sociais ou artificiais que ganham espaço nas manchetes dos jornais e tornam-se notícias estridentes e emergenciais. Já os acontecimentos são de outra natureza: silenciosos e insensíveis, passando à margem de qualquer representação ou racionalização.

O Acontecimento seria aquilo que provoca crise, um fato único e excepcional, imprevisível e jamais repetível. Seria aquilo que cai sobre mim. O Acontecimento provoca uma ruptura, altera a vivência. Depois dele já não sou mais o mesmo.

Deleuze sustenta que essa experiência do Acontecimento não é apenas passiva como alguém que sofre a ação de um evento inesperado como a morte (DELEUZE, 1974). Diante do Acontecimento procuramos um sentido; retroagimos para tentar entender suas causas. Por isso, o Acontecimento pode ter um sentido individual, pessoal (a construção de um significado a partir da construção de uma sequência temporal privada). Mas, como afirma outro filósofo francês Jacques Derrida, temos o plano do sintoma, um plano metafísico independente das significações particulares atribuídas (DERRIDA, 2006). Para Derrida, o sintoma seria essa busca da verdade sobre o Acontecimento.

Nesse ponto, podemos estabelecer uma conexão com a proposta de Horsley em ver o cinema ao mesmo tempo como diagnóstico e sintoma coletivos. Os filmes esquizo emergiram justamente quando acontecimentos sacudiram o imaginário coletivo como a Segunda Guerra Mundial, as experiências nucleares no Deserto de Nevada e o crescimento de Las Vegas como polo irradiador do jogo e ilusão. Da mesma forma, a Guerra do Vietnã e a aceleração das transformações culturais com a evanescente cultura pop nas décadas de 1960-70 propiciaram os anti-heróis cínicos e revoltados da filmografia da época.

Sobre o plano físico das buscas pessoais de sentido haveria a dimensão, por assim dizer, metafísica do sintoma, dos registros culturais ou midiáticos que constroem um significado coletivo.

Mas ainda estamos em uma discussão filosófica sobre a noção de Acontecimento. Nada ainda sabemos sobre a relação entre Acontecimento e Comunicação. Por enquanto, estamos tentando estabelecer processos ou, em outras palavras, a forma como o Cinema representa os acontecimentos ou eventos na forma de sintoma. Resta saber se esses filmes esquizo de fato comunicam, isto é, produzem Acontecimento para o espectador, provocam espanto, assombro, mal estar, mudança.

Ciro Marcondes Filho nos apresenta uma crítica ao mesmo tempo ontológica e metodológica sobre a Comunicação (MARCONDES FILHO, 2010). Para ele, até aqui toda a teoria da comunicação vem apenas contornando ou dando voltas em torno do seu objeto. Os fenômenos comunicacionais, sejam eles midiáticos ou interpessoais, sempre foram analisados a posteriori, depois de encerrado o calor do acontecimento dos eventos. Por isso, as sucessivas formas de representação do fenômeno (linguística, sociológica, filosófica, psicológica etc.) nunca conseguem captar a própria ontologia dos fenômenos comunicacionais: o Acontecimento - sua manifestação, denegação ou mesmo inexistência. 
Para fundamentar essa crítica, Marcondes Filho estabelece uma distinção entre os conceitos de sinalização, informação e comunicação. Sinalizar está relacionado com as diversas estratégias midiáticas em criar signos distintivos para reconhecimento do receptor, estratégias para chamar a atenção, fisgar, manipular, seduzir, convencer, ou seja, agir sobre o outro. No caso do cinema as convenções de gêneros, estilos, estratégias retóricas etc. A informação corresponderia ao plano da escolha do receptor: uma vez retirado da sua indiferença em relação às sinalizações das mídias, o receptor seleciona informações que aditivam, complementam um repertório pré-existente. Aqui ainda não há a dissonância, a contradição, já que as informações apenas têm a função de atualização ou soma.

Diferente é o caso da Comunicação, pois temos um Acontecimento que nos confronta, interfere na forma de ver o mundo e as pessoas, transforma. É o novo.

No cinema podemos perceber essa diferença entre informação e comunicação na habitual forma como espectadores selecionam o filme que vão assistir a partir de opiniões de críticos, sinopses em publicações especializadas ou a partir de recomendações de amigos que partilham de um gosto estético semelhante. $\mathrm{Na}$ maior parte do tempo o espectador se encontraria no nível da informação. Nada há de novo ou dissonante, a não ser quando o filme não corresponde à expectativa ou as informações anteriormente aferidas resultando em simples frustração.

De outra ordem é o fenômeno da Comunicação cuja ontologia aproxima-se da noção de Acontecimento. Por isso, ao contrário da informação, a Comunicação ocorreria em outro tempo, diferente tanto da sequência temporal do cotidiano quanto do tempo da informação caracterizado pela repetição e adição. Marcondes Filho denomina o tempo da Comunicação como "metapórico":

“(...) Num certo momento, ocorre a virada, a transformação, a revelação. Deu-se um fato sensivel que justifica ofenômeno da comunicação. (...) Mas há aqueles fenômenos que provocam o choque sem condiçóes prévia e cujos efeitos se fazem sentir a posteriori. O cinema, a música, a contemplação estética em geral, a paixão provocam o choque, o êxtase, o transe, em suma, os elementos que me transportam para o outro mundo e que permitem, através deles, realizar essa 'apropriação metafísica', de que fala Bergson, isso é, o sentido. Nesse caso, a intuição intelectual é posterior, o tratamento daquilo que me transformou se dá em mim no após." (...) Existe um pico, que é a intuição sensivel, momento da virada, mas existe uma temporalidade prévia ou posterior que constitui o fenômeno e que não pode ser desprezada, ou seja, a temporalidade metapórica é uma temporalidade estendida marcada pelos picos de êxtase. Quando saio de uma sessão cinematográfica, o vivido continua em mim repercutindo por algum tempo. O sensivel foi incorporado alterando-me, já pode ser intelectualizado." (MARCONDES FILHO, 2010, pp. 254-255)

Aqui temos o tempo metapórico do Acontecimento em um duplo aspecto: de um lado como um golpe, êxtase, o caráter repentino e, do outro, como natureza subterrânea, sísmica, uma efetuação lenta que, só mais tarde, tomaremos consciência tornando o evento passado em um Acontecimento.

\section{Considerações Finais}

A partir dos conceitos de Acontecimento e Comunicação, poderíamos definir como principal objetivo de uma futura pesquisa sobre a experiência cinematográfica 
a tentativa de capturar e refletir sobre o momento incorpóreo e efêmero do encontro entre a jornada da narrativa fílmica com a jornada pessoal do espectador, o momento em que a recepção do conteúdo e forma cinematográficos transformados em sintomas pode criar rupturas ou fendas na temporalidade cotidiana. Em outras palavras, procurar capturar e refletir os "incorpóreos" que perpassam o "contínuo midiático atmosférico” (MARCONDES FILHO, 2010) e que podem produzir acontecimentos no momento em que o sintoma materializado em produtos culturais como o filme vai se interseccionar com a própria trajetória de vida do espectador. E o resultado disso seriam experiências de quebra de limites, mal estar e mecanismos de defesa psíquicos em reação ao novo ou ao sintoma.

Embora o cinema represente um sintoma social ele é, ao mesmo tempo, um elemento operacional do sistema (o "contínuo midiático") que oferece entretenimento e alimenta o fluxo de imagens e informações. Mas, em certos momentos e em dados contextos alguma coisa sai do prumo, surge uma fugaz nova temporalidade, recombinações estranhas, instabilidades... acontecimentos - ou os "incorpóreos" como eventos que intervêm transversalmente nesse contínuo midiático.

O objetivo de tentar capturar e refletir esses "incorpóreos" no momento da sua manifestação criaria um desafio metodológico para a pesquisa: um projeto que procurasse estudar as conexões entre Cinema e Acontecimento Comunicacional não poderia se confundir com o tradicional quadro conceitual dos estudos de recepção.

Se partirmos da categorização das ciências proposto por Habermas (ciências empírico-analíticas, histórico-hermenêuticas e críticas) esse estudo se basearia no "interesse emancipador" das ciências críticas (HABERMAS, 1982). Acreditamos que dentro do campo das análises que procuram estudar os "efeitos" e a "recepção" das mídias tanto nas audiências quanto em indivíduos, tal estudo seria relevante ao colaborar com uma abordagem que pretenderia estudar o fenômeno comunicacional em si, para além dos fenômenos de sinalização (percepção, apreensão ou compreensão de signos imediatos - modelos hipodérmicos, Mass Communication Research etc.) ou de informação (efeitos de reforço, manipulação, seletividade, pré-disposição etc. Estudos Culturais, Agenda Setting, Teoria da Informação, entre outras).

E dentro do campo dos estudos sobre o Cinema, dominado por enfoques linguísticos, semióticos e político-ideológicos, um projeto de estudos que procurasse as convergências entre Cinema e Acontecimento Comunicacional viria se filiar a uma tradição fenomenológica iniciada por Henri Bergson ao relacionar o aparato cinematográfico com própria maneira como apreendemos intelectualmente a realidade como uma sucessão de quadros estáticos que cliva o espaço-movimento (BERGSON, 1999 e 2001). Se Bergson apresenta o cinema como “imagem-movimento", isto é, o cinema preso no presente por reproduzir tecnologicamente o modelo do intelecto (a analogia do cinema com a caverna platônica), Deleuze compreenderá no cinema novas formas de exploração que vão para além do movimento do tempo: a exploração do tempo - imagens-lembrança, imagens-sonho (DELEUZE, 2004 e 2006).

A ruptura dos elos sensório-motores do cinema clássico (imagem-ação e imagem- movimento) possibilitaria novas formas de apreensão fílmica que poderiam criar no espectador experiências temporais metapóricas (acontecimentos) como, por exemplo, desconstrução da realidade consensual, mudanças na realidade temporal e espacial etc.

Um exemplo atual desse tipo de pesquisa fenomenológica sobre o Cinema é a realizada pelo diretor de cinema independente e pesquisador norte-americano Mark 
Allan Kaplan. Ele vem desenvolvendo nos últimos anos o que ele denominou por "Transpersonal Cinema Project" onde explora o "cinema de transformação e transcendência": pesquisa que pretende explorar o potencial de transformação na experiência estética do cinema, integrando as mais recentes teorias, práticas e tecnologias da mídia cinematográfica com a percepção e consciência humana (KAPLAN, 2012).

Embora suas noções de "transcendência" e "transformação" estejam carregadas com o pragmatismo do ideário do espiritualismo da autoajuda norte-americana ("cura", "crescimento pessoal" etc.) a chamada "Teoria do Cinema Integral" desenvolvida por Kaplan pode nos oferecer interessantes ferramentas de pesquisa empírica que procuram capturar e refletir experiências tão qualitativas, incorpóreas e fugidias como as sugeridas nesse presente artigo.

Se fizermos uma conexão entre a proposta do "Transpersonal Cinema" de Kaplan (que procura na experiência cinematográfica momentos de transcendência dos limites do $\mathrm{Eu}$, do mundo e da própria linguagem cinematográfica) e a Teoria do tempo metapórico do Acontecimento em Marcondes Filho, poderíamos desenvolver um conjunto inicial de ferramentas conceituais aplicáveis para um estudo fenomenológico sobre a experiência cinematográfica do espectador:

Experiências de ressonância cinemática de conteúdos na trajetória de vida do espectador - como a realidade ficcional filmica repercute na realidade pessoal, interpessoal e coletiva do espectador (diferente da noção tradicional de "identificação" dos estudos de recepção que se limita ao mero reconhecimento de sinalizações) capaz de expressar transformações, experiência de transcendência. Por "transcendência" entendemos a capacidade da experiência da cena fílmica empreender uma "descontinuidade" (estranhamento, alienação, mal estar etc.) no retorno do espectador a sua vida cotidiana;

Indução cinemática onde a estética fílmica (fotografia, design, efeitos especiais, montagem etc.) poderia criar estados alterados de consciência como paranoia, melancolia e suspensão - estados de estranhamento e alienação potencialmente críticos diante da realidade;

Incomunicabilidade Cinemática: tentativa de verificar e mapear as formações reativas do espectador diante de uma experiência que o incomode ou quebre expectativas da seletividade ao nível da informação: racionalizações, agressividade, negação, sono, bocejo, "pernas nervosas" etc.

Quebra-da-Ordem-e-Retorno-a-Ordem: temos o esquema da liberação de elementos transgressivos ou desestabilizadores da ordem moral ou política até certo ponto da narrativa, para, ao final ou na próxima sequência, retornar à ordem convencional no cinema comercial. Mas se o cinema é uma mídia baseada na mitologia, ilusão e mágica (elementos potencialmente desreguladores e capazes de produzir "incorpóreos" na temporalidade cotidiana do espectador), então continuamente a experiência filmica pode produzir impacto, descontinuidade e mal estar no momento em que as luzes do cinema se acendem jogando o espectador de volta à rotina.

\section{Referências Bibliográficas}

ADORNO, Theodor. Dialéctica Negativa, Madrid: Taurus, 1991. ,Theodor, "Sobre Música Popular", In: COHN, Gabriel (org.) Theodor

W. Adorno, Coleção Grandes Cientistas Sociais, São Paulo: Ática,1986.

BERGSON, Henri. Matéria e Memória. São Paulo: Martins Fontes, 1999. 
, Henri. A Evolução Criadora, Lisboa: Edições 70, 2001.

DELEUZE, G. Lógica do Sentido. São Paulo: Perspectiva, 1974 , Gilles. A Imagem-Movimento-Cinema 1, Lisboa: Assírio \& Alvim,

2004 , Gilles. A Imagem-Tempo - Cinema 2, Lisboa: Assírio \& Alvim, 2006.

DERRIDA, Jacques, Soussana, G., Nouss, A. Decir el acontecimiento. Es posible? Arena Libros, Madri, 2006.

FERREIRA, Wilson Roberto V. "Somos todos Viajantes, Detetives e Estrangeiro”, In: Cinema Secreto: Cinegnose, 2012. Disponível em <http://cinegnose.blogspot. com.br/2011/09/somos-todos-viajantes-detetives-e.html> Acesso em 02/10/2012.

HABERMAS, Jürgen. Conhecimento e Interesse. Rio de Janeiro: Zahar, 1982.

HORSLEY, Jason. The Secret Life of Movies - Schizophrenic and Shamanic Journeys in American Cinema. McFarland, 2009.

IPSOS \& REUTERS, "On Eve of 82nd Annual Academy Awards, 42\% of Global Citizens Say they Use Movies and Films as Their Escape from Real World-Watching as Many as They Can as Often as They Can"In: Ipsos.com, 2010. Disponível em < http:// www.ipsos-na.com/news-polls/pressrelease. aspx?id=4704 > Acesso em 15/07/2015.

MARCONDES FILHO, Ciro, O Princípio da Razão Durante - O conceito de comunicação e a epistemologia metapórica. São Paulo: Paulus, 2010.

PROKOP, Dieter, "Fascinação e Tédio na Comunicação: produtos de monopólio e consciência”, In: MARCONDES FILHO, Ciro (org.) Dieter Prokop, Coleção Grandes Cientistas Sociais, São Paulo: Ática, 1986.

ROSS, Steven J. Working Class Hollywood, Princeton: Princeton University Press, 1999. 


\section{Entrevista com Frei Alamiro}

José Alamiro Andrade Silva (27/05/1940) nasceu em Três Pontas e em sua caminhada passou por momentos fortes da vida do povo pobre de nosso país. Esteve na luta em defesa dos direitos humanos e da luta pela anistia, ao lado do prêmio Nobel da Paz Adolfo Pérez Esquivel. Solidário como os mais fracos, nos dramáticos enfrentamentos com a repressão ao movimento dos trabalhadores em São Bernardo, continua um militante da "firmeza permanente", como ele prefere chamar esse modo de construir um mundo novo, sem injustiças e exploração.

A entrevista recupera momentos da história recente de nosso povo e valoriza a persistência em ideais de mudança e luta pela paz e pela justiça, como as greves de São Bernardo e ações para salvar vidas da repressão no Brasil e na América Latina.

C \& LC - Comecemos sobre a origem do convento Santo Antônio do Largo da Carioca, Rio de Janeiro. Frei Vicente de Salvador, fundador deste convento, é o autor da primeira história do Brasil. Isso confirma a importância dos religiosos na formação cultural brasileira?

Considerando a formação cultural brasileira a partir da chegada dos europeus, quando Pedro Álvares Cabral chega ao Brasil, junto dele vieram 12 franciscanos, entre eles Frei Henrique de Coimbra, que presidia o grupo.

Não se pode negar que eles vieram entusiasmados para pregar o Evangelho por toda a parte, mas os primeiros franciscanos não vieram apenas com intenções religiosas. Naquela época, a Igreja, através das suas Congregações, era detentora do saber, inclusive do saber científico. Muitos deles vieram porque conheciam as rotas através das estrelas, vieram como assessores científicos para que Pedro Álvares Cabral chegasse aonde ele tinha que chegar.

Os franciscanos e as outras ordens religiosas participaram decisivamente desta formação, por exemplo, o primeiro nome do país era Terra de Santa Cruz, depois é que prevaleceu o nome comercial de Pau-Brasil.

Entre os franciscanos, jesuítas e carmelitas, que também estavam muito presentes naquela época, segundo o historiador uruguaio Mario Cayota os que tinham a melhor acolhida popular em toda a América Latina, principalmente da parte dos índios, eram os seguidores de Francisco. Os índios diziam: "Eles são iguais a nós, andam descalços e estão próximos”. Você pode ver que na América as igrejas franciscanas têm um influxo popular muito grande. Uma série de fatores que levaram - os Capuchinhos ainda mais do que nós - a uma proximidade, uma integração com o povo.

Estiveram muito presentes, logo no começo, deste convento e o de Olinda. Mas presentes sempre dentro daquele contexto de padroado, no qual quem nomeava o 